Michael D. Kornberg,

$\mathrm{MD}, \mathrm{PhD}$

Scott D. Newsome, DO

Neurol Neuroimmunol Neuroinflamm

2015;2:e66; doi: 10.1212/ NXI.0000000000000066

\section{UNMASKING AND PROVOKING SEVERE DISEASE ACTIVITY IN A PATIENT WITH NMO SPECTRUM DISORDER \\ OPEN}

Neuromyelitis optica (NMO) is often not considered in patients with brain lesions in the absence of longitudinally extensive spinal cord lesions. When first-line therapies for multiple sclerosis (MS) fail, treatment is often escalated to natalizumab. We present a case of fulminant NMO spectrum disorder (NMOSD) relapse shortly after initiation of natalizumab in a patient previously suspected of having MS. This patient's course was complicated because disease activity continued even after transitioning to rituximab and having undetectable B cells.

Case report. A 33-year-old woman with a diagnosis of MS transferred to our hospital in November 2013 for rapidly progressive neurologic symptoms. She first presented in early 2012 for right leg weakness. MRI revealed scattered white matter lesions (no callosal lesions) and a short-segment thoracic cord lesion that raised suspicion for MS (figure, A). CSF revealed no pleocytosis, normal protein/glucose, normal immunoglobulin (Ig) $G$ index, and one oligoclonal band. Fingolimod was initiated. Over the ensuing year, she had 2 minor relapses with nearly complete recovery. Repeat MRI in September 2013 showed multiple new brain lesions (figure, B). She was switched to natalizumab after serum JC virus antibody testing was negative. Spine MRI showed no new lesions.

After her second dose of natalizumab, she was admitted to an outside hospital for rapid onset of dysarthria, dysphagia, and quadriplegia. She failed to respond to IV methylprednisolone and required intubation. She was subsequently transferred to our institution. On arrival, examination revealed decreased responsiveness with quadriplegia, trismus, and autonomic instability. MRI brain revealed marked progression of disease (figure, C). MRI spine revealed a new longitudinally extensive lesion from T6-T12 (figure, D) without clear contrast enhancement. The diagnosis of MS was questioned and further workup was pursued. Lumbar puncture was unremarkable: no pleocytosis, normal protein and glucose, normal IgG index, no oligoclonal bands, and negative for infections, including progressive multifocal leukoencephalopthy. Cerebral angiogram showed no vasculopathy. Brain biopsy ruled out nondemyelinating disorders.

Inflammatory/rheumatologic testing was negative except for aquaporin-4 (AQP4) antibody ELISA assay $(>160 \mathrm{U} / \mathrm{mL}$, normal $<5 \mathrm{U} / \mathrm{mL})$. She was therefore diagnosed with NMOSD. She received 5 sessions of plasma exchange with significant improvement, although she required tracheostomy and gastric tube placement. On discharge, she was awake, alert, and following commands, but was paraplegic. Rituximab was commenced.

Four weeks after rituximab, she experienced a relapse with decreased speech output and worsening right-sided weakness. This occurred in the context of zero CD19/CD20 B cells. MRI revealed new enhancing lesions in the brachium pontis and cervical spinal cord (figure, E and F). She received IV methylprednisolone with moderate improvement. On follow-up, she had improved strength/speech and was able to perform some of her activities of daily living. It is unclear whether this relapse represented rituximab failure, given that it had only recently been initiated. She is being followed closely, with consideration of combination immunosuppressant therapy.

Discussion. This case suggests that natalizumab can precipitate a dramatic flare-up of $\mathrm{NMO} /$ NMOSD, especially after fingolimod therapy. Although not definitive, the timing of events is highly suggestive, and case reports such as this play a critical role in identifying clinical concerns that merit further systematic investigation. Previous reports have indicated that natalizumab and fingolimod are ineffective in $\mathrm{NMO}$, and some have suggested that they may exacerbate disease. ${ }^{1,2}$ Natalizumab blocks the interaction between $\alpha 4 \beta 1$ integrin and vascular cell adhesion molecule-1 to prevent entry of leukocytes into the CNS. However, natalizumab has differential effects on inflammatory cells, which may explain its potential to worsen NMO. Natalizumab increases circulating B cells, which may enhance humoral autoimmunity. ${ }^{3}$ Furthermore, natalizumab fails to prevent CNS migration of Th17 lymphocytes, which have been shown to play a preferential role 


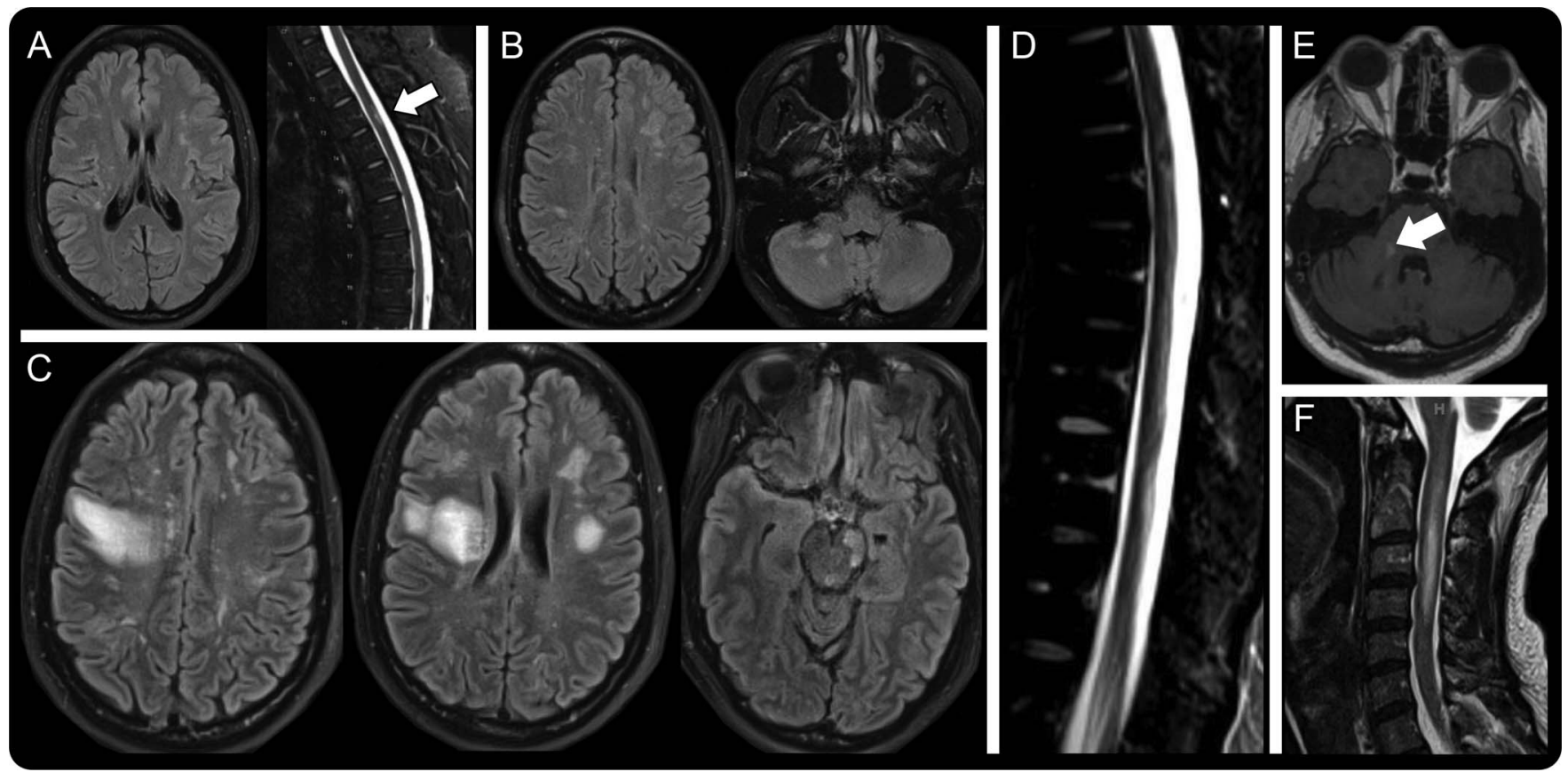

(A) MRI from February 2012. Axial fluid-attenuated inversion recovery (FLAIR) and sagittal T2 scans reveal scattered white matter lesions and a shortsegment lesion at T3 (arrow). (B) MRI from September 2013. Axial FLAIR images reveal progression of disease from prior imaging. (C, D) MRI after second natalizumab treatment in November 2013. Axial FLAIR images (C) reveal marked progression, and sagittal T2 scan (D) reveals a longitudinally extensive lesion from T6 to T12. (E, F) MRI demonstrating relapse after initiation of rituximab. Axial T1 postcontrast (E) shows an enhancing lesion in the brachium pontis, and sagittal T2 (F) reveals a new cervical lesion.

in NMO. 4,5 Although speculative, the relative "unmasking" of Th17 cells may lead to increased disease activity. In our case, treatment with fingolimod may have set the stage for a more severe NMOSD relapse by affecting vascular endothelial cells and increasing blood-brain barrier permeability, allowing for a robust influx of Th17 lymphocytes into the CNS. ${ }^{6}$ The initial inadequate response to rituximab may directly relate to this uninhibited Th17 response.

This case also highlights the importance of maintaining suspicion for NMO/NMOSD even in the presence of brain lesions and the absence of a long cord lesion at onset. Although NMO classically spares the brain parenchyma, $60 \%$ of patients with NMO develop nonspecific white matter lesions, with $10 \%$ meeting radiographic criteria for MS.?

Overall, this case illustrates the potential consequences of misdiagnosis in NMOSD. Testing for AQP4 antibody should be considered in all patients who present with features atypical for MS, particularly if they fail to respond to initial therapies. Furthermore, natalizumab and fingolimod should be avoided when NMO remains a diagnostic possibility.

From the Department of Neurology, Johns Hopkins University, Baltimore, $M D$.

Author contributions: Conceptualization of the report: Michael Kornberg, Scott Newsome. Data collection: Michael Kornberg.
Analysis/interpretation of the data: Michael Kornberg, Scott Newsome. Drafting/revising the manuscript: Michael Kornberg, Scott Newsome.

Study funding: No targeted funding reported.

Disclosure: M.D. Kornberg has received research support from the National Institute of Neurological Disorders and Stroke. S.D. Newsome is on the scientific advisory board for Genzyme and Novartis and has received research support from Biogen Idec and Novartis. Go to Neurology.org/nn for full disclosures. The Article Processing Charge was paid by the authors.

This is an open access article distributed under the terms of the Creative Commons Attribution-Noncommercial No Derivative $3.0 \mathrm{Li}$ cense, which permits downloading and sharing the work provided it is properly cited. The work cannot be changed in any way or used commercially.

Received September 9, 2014. Accepted in final form December 4, 2014. Correspondence to Dr. Newsome: snewsom2@jhmi.edu

1. Jacob A, Hutchinson M, Elsone L, et al. Does natalizumab therapy worsen neuromyelitis optica? Neurology 2012;79: 1065-1066.

2. Min JH, Kim BJ, Lee KH. Development of extensive brain lesions following fingolimod (FTY720) treatment in a patient with neuromyelitis optica spectrum disorder. Mult Scler 2012;18:113-115.

3. Krumbholz M, Meinl I, Kumpfel T, Hohlfeld R, Meinl E. Natalizumab disproportionately increases circulating pre- $\mathrm{B}$ and B cells in multiple sclerosis. Neurology 2008;71:1350-1354.

4. Rothhamer V, Heink S, Petermann F, et al. Th17 lymphocytes traffic to the central nervous system independently of $\alpha 4$ integrin expression during EAE. J Exp Med 2011;208: 2465-2476. 
5. Wang HH, Dai YQ, Qiu W, et al. Interleukin-17-secreting $\mathrm{T}$ cells in neuromyelitis optica and multiple sclerosis during relapse. J Clin Neurosci 2011;18:1313-1317.

6. Cannon RE, Peart JC, Hawkins BT, Campos CR, Miller DS. Targeting blood-brain barrier sphingolipid signaling reduces basal P-glycoprotien activity and improves drug delivery to the brain. Proc Natl Acad Sci U S A 2012;109:15930-15935.

7. Pittock SJ, Lennon VA, Krecke K, Wingerchuk DM, Lucchinetti CF, Weinshenker BG. Brain abnormalities in neuromyelitis optica. Arch Neurol 2006;63:390-396. 


\section{Neurology \\ Neuroimmunology \& Neuroinflammation}

\section{Unmasking and provoking severe disease activity in a patient with NMO spectrum disorder}

Michael D. Kornberg and Scott D. Newsome

Neurol Neuroimmunol Neuroinflamm 2015;2;

DOI 10.1212/NXI.0000000000000066

\section{This information is current as of February 12, 2015}

Updated Information \&

Services

References

Subspecialty Collections

Permissions \& Licensing

Reprints including high resolution figures, can be found at:

http://nn.neurology.org/content/2/2/e66.full.html

This article cites 7 articles, 2 of which you can access for free at: http://nn.neurology.org/content/2/2/e66.full.html\#\#ref-list-1

This article, along with others on similar topics, appears in the following collection(s):

All Demyelinating disease (CNS)

http://nn.neurology.org//cgi/collection/all_demyelinating_disease_cns Autoimmune diseases

http://nn.neurology.org//cgi/collection/autoimmune_diseases

Devic's syndrome

http://nn.neurology.org//cgi/collection/devics_syndrome

Information about reproducing this article in parts (figures,tables) or in its entirety can be found online at:

http://nn.neurology.org/misc/about.xhtml\#permissions

Information about ordering reprints can be found online: http://nn.neurology.org/misc/addir.xhtml\#reprintsus

Neurol Neuroimmunol Neuroinflamm is an official journal of the American Academy of Neurology.

Published since April 2014, it is an open-access, online-only, continuous publication journal. Copyright $(0$ 2015 American Academy of Neurology. All rights reserved. Online ISSN: 2332-7812.

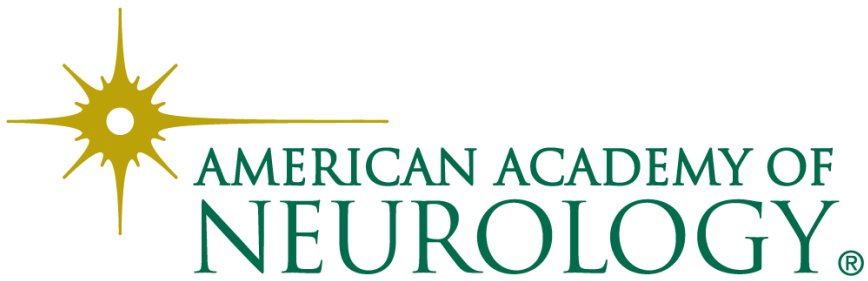

